九州大学学術情報リポジトリ

Kyushu University Institutional Repository

\title{
Notes on the Nest Architecture of Halictus senilis (Eversmann) in Southeast Kazakhstan (Hymenoptera, Halictidae)
}

Miyanaga, Ryoichi

Division of Environmental Biology, Faculty of Life and Environmental Science, Shimane University, Nishikawatsu, Matsue

Tadauchi, 0samu

Entomological Laboratory, Faculty of Agriculture, Kyushu University, Fukuoka

Murao, Ryuki

Entomological Laboratory, Graduate School of Bioresource and Bioenvironmental Sciences, Kyushu University, Fukuoka

https://doi.org/10.5109/2854

出版情報: ESAKIA. 46，pp.21-23，2006-06-30. Entomological Laboratory, Faculty of Agriculture, Kyushu University

バージョン：

権利関係 : 


\title{
Notes on the Nest Architecture of Halictus senilis (Eversmann) in Southeast Kazakhstan (Hymenoptera, Halictidae)
}

\author{
Ryoichi Miyanaga $^{1)}$, Osamu Tadauchi ${ }^{2)}$ and Ryuki Murao ${ }^{3)}$ \\ 1) Division of Environmental Biology, Faculty of Life and Environmental Science, \\ Shimane University, Nishikawatsu, Matsue, 690-8504 Japan \\ 2) Entomological Laboratory, Faculty of Agriculture, Kyushu University, Fukuoka, \\ 812-8581 Japan \\ 3) Entomological Laboratory, Graduate School of Bioresource and Bioenvironmen- \\ tal Sciences, Kyushu University, Fukuoka, 812-8581 Japan
}

\begin{abstract}
Four nests of Halictus senilis (Eversmann) were excavated near Chimkent, southeast Kazakhstan. The nest of H. senilis was similar in structure to nests of the other species of Halictus s. s., i.e., each cell directly, not by means of lateral, connected to the main burrow. On the other hand, the deviation from the typical nest structure of Halictus was found. The coexistence of delayed eusocial and solitary nests was suggested in this species.
\end{abstract}

Key words: Hymenoptera, Halictidae, nest architecture, sociality, Kazakhstan

\section{Introduction}

In our field studies on wild bee fauna and pollination biology for combating desertification and planting campaigns in Asian arid areas from 2000 to 2004, we aimed to discover important pollinators for native plants and study nesting behaviors, as well as conduct taxonomic and biogeographical studies (Tadauchi, 2005). We published our study of the taxonomy and nest architecture of Andrena (Euandrena) almas from Xinjiang Uygur, China (Tadauchi et al., 2005). This is the second report of nest architecture on wild bees in our field studies. We found and excavated four nests of Halictus senilis (Eversmann) in southeast Kazakhstan. The nest structure of H. senilis has been previously reported by Popov (1967) and Marikovskaya (1972), but without detailed descriptions of the nest pattern. In this paper details of nest structure and pattern are provided, and significance of the findings is discussed.

\section{Results and Discussion}

Nest site

Four nests of $H$. senilis were excavated on May 5 and 8, 2004 (Fig. 1A-E). Two, out of the four nests (nests A and B) were found on the sandy roadside near Murunkarak (nose of the desert, $42^{\circ} 16^{\prime} \mathrm{N}, 67^{\circ} 45^{\prime} \mathrm{E}$, Fig. 2A) hill in Kyzylkum desert, $130 \mathrm{~km}$ west of Chimkent. Both nests were found in an embankment of loose and powdery sand, in the sparse vegetated desert (Fig. 2B). The other two nests (Nests C and D) were found at the riverside of Syrdarya, near Polevod village $\left(42^{\circ} 12^{\prime} \mathrm{N}\right.$, $\left.68^{\circ} 20^{\prime} \mathrm{E}\right), 100 \mathrm{~km}$ west of Chimkent. The nests were on the embankment between a wheel track in the riparian forests (Fig. 2C).

Nest architecture

The description of nest architecture is mainly based on Nests A and B. The nest of $H$. senilis belongs to pattern IIIc of Sakagami and Michener (1962), i.e., cells are concentrated and each is directly, not by means of lateral, connected to main burrow (Fig. 2D). The nest entrance was circular, $3.7-4.9 \mathrm{~mm}$ in diameter $(\mathrm{X}=4.5 \mathrm{~mm}$, $\mathrm{N}=4$ ) and surrounded by a radial tumulus without a turret. There was no special enlargement immediately below the entrance. The main burrow widened to 5.5-7.2 $\mathrm{mm}$ in diameter $(\mathrm{X}=6.8 \mathrm{~mm}, \mathrm{~N}=4)$, and descended nearly vertical or declined slightly towards the bottom end. Some nests had a short ramified burrow 5.0-5.2 $\mathrm{mm}$ in width, which was narrower than the main burrow. The depth of the main burrow was $100-310 \mathrm{~mm}(X=290.0$

E-mail: miyanaga@life.shimane-u.ac.jp 


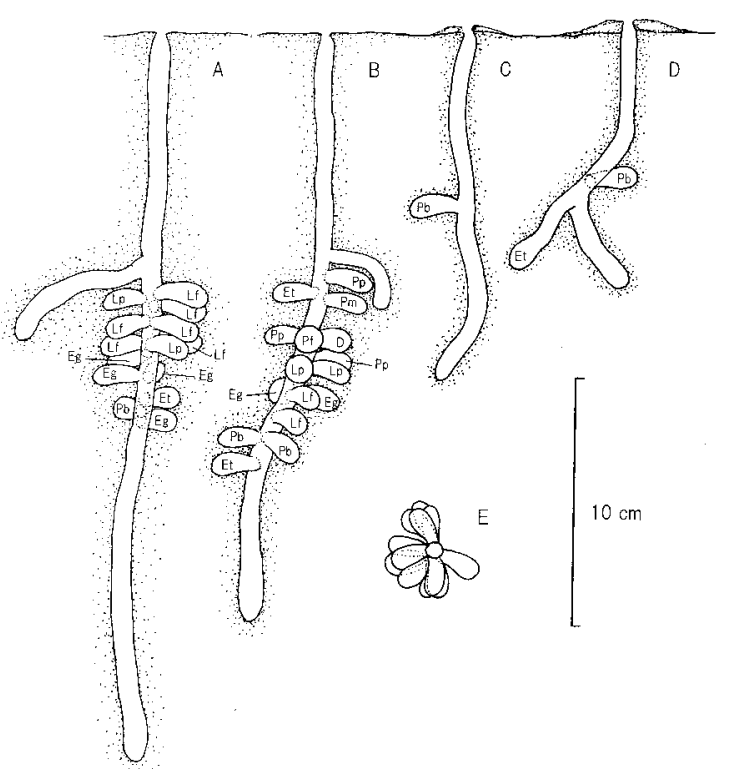

Fig. 1. Nests of H. senilis. The symbols inside the cells are as follows: $\mathrm{Et}=$ empty cell; $\mathrm{Pb}=$ pollen ball only; $\mathrm{Eg}=$ pollen ball with egg; Lf = feeding larva; Lp:post feeding larva; Pp: prepupa; Pm: male pupa; Pf: female pupa. $\mathrm{mm}, \mathrm{n}=4)$.

Cells slightly declined downwards, and their shape was typical of those built by other halictine bees, i.e., in possessing an oval room with a flat underside floor. The size of cells was $9.0-13.9 \mathrm{~mm}$ in length $(\mathrm{X}=12.5$ $\mathrm{mm}, \mathrm{N}=22$ ) and $5.8-7.2 \mathrm{~mm}$ in width at the largest part $(\mathrm{X}=6.4 \mathrm{~mm}, \mathrm{~N}=22)$. The inner wall was smooth and coated with a lining, except for the entrance which possessed a diameter of $3.0-4.8 \mathrm{~mm}$ at the neck $(X=3.5 \mathrm{~mm}$, $\mathrm{N}=13$ ). The shape of pollen balls was round with a flattened bottom, 4.4-4.8 $\mathrm{mm}$ in diameter $(\mathrm{X}=4.7 \mathrm{~mm}, \mathrm{~N}=4)$ with eggs being laid on top of balls. Cells containing an egg were sealed with a plug of loose soil. Generally, cells of each brood extended in all directions from the burrow. However, many of the cells in Nest B were concentrated one side of a burrow (Fig. 1E).

The cells tended to be closely clustered along the short range of burrows. The uppermost cell was at a depth of $100 \mathrm{~mm}$ in Nest B, while the lowermost cell was at a depth of $150 \mathrm{~mm}$. Fifteen cells were clustered together within a $50 \mathrm{~mm}$ section of the main burrow (Fig. 1B). Similarly, 16 cells were found in an $80 \mathrm{~mm}$ section of the main burrow (between a depth of 130

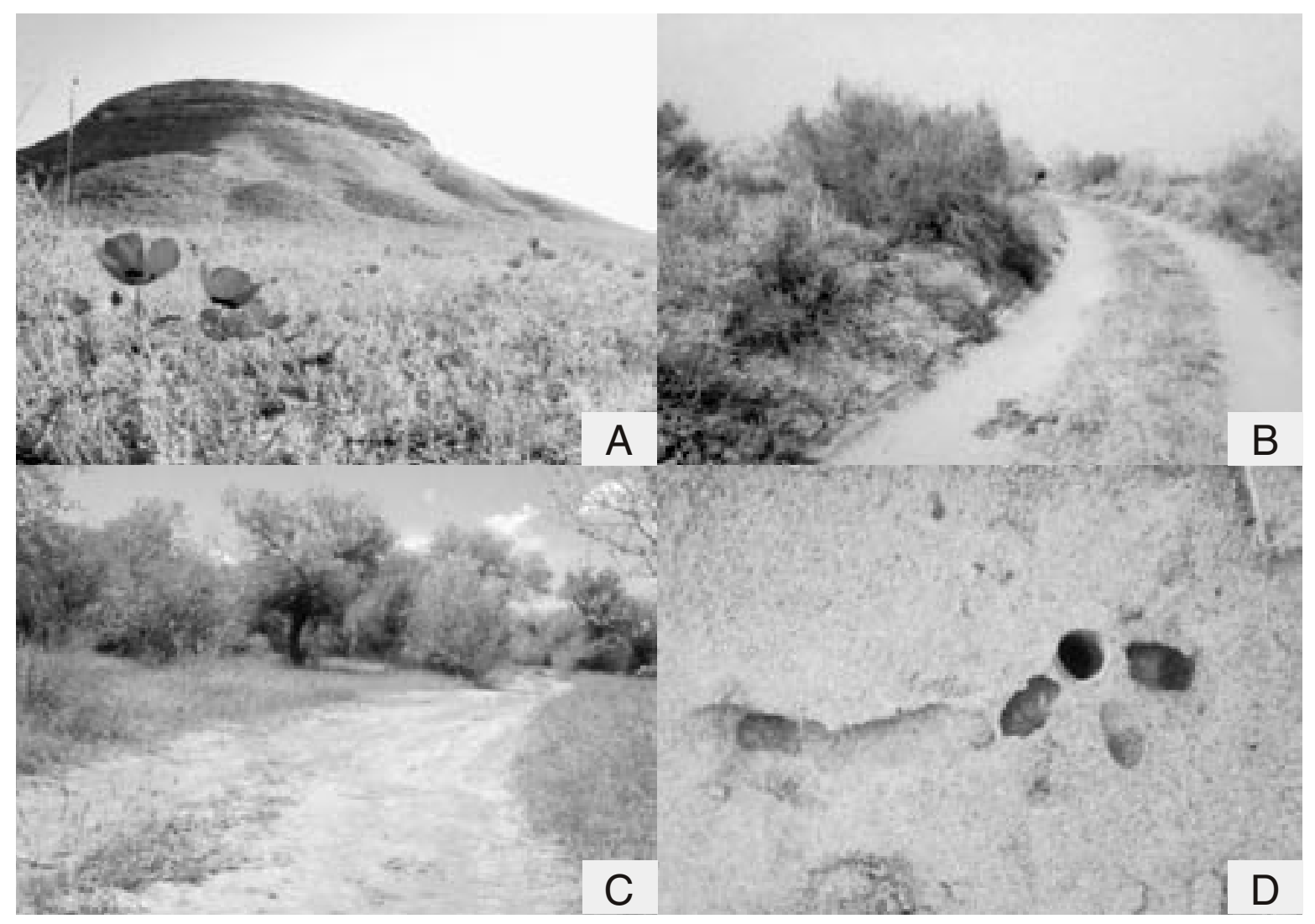

Fig. 2. Nest site of Halictus senilis. A: Murunkarak hill; B: Road in the Kyzylkum desert; C: Road in the riparian forest at Syrdarya River; D: Concentrated cells of H. senilis (Nest 2). 
and $210 \mathrm{~mm}$ ) (Fig. 1A). The presence of a short branch (19.8 mm in length) around the brood cell in Nest B is interesting (Fig. 1B). The branch ran close to the uppermost cell, and curved downward to surround the cells. It might represent an incipient stage towards cavity formation.

According to Popov (1967), H. senilis builds a cavity around a cell cluster (nest pattern IV). However, judging from the description and diagram by Marikovskaya (1972), the pattern of nests she excavated belongs to type IIIc. In the genus Halictus, most nests recorded for species, share a common nest structure with sessile cells arising from the burrow without cavity formation (Sakagami \& Michener, 1962). The cavity builder is rare. Packer \& Knerer (1986) reported the presence of looped branches around the brood cell in H. ligatus, and mentioned the possibility of cavity construction in this species. The short lateral branch around the cell in Nest $\mathrm{B}$ might be a comparable structure. In halictine bees, the coexistence of different types of nest pattern in the same species was reported in Lasioglossum albescens (Matsumura \& Sakagami, 1971; Batra, 1966).

The cell arrangement was generally progressive, indicating that cells were made from the upper to lowermost region (Malyshev, 1935). A close succession in preparing each cell, suggested by the cell contents of Nests A and B, shows the possibility of multi-female nesting in these nests, although only one female was found in each nest, when excavated. Marikovskaya (1972) found two females in spring nests of $H$. senilis. She supposed that the social type in such nests is a delayed type of eusociality, an association between the mother and her daughter after passing the winter together, although she did not provide detailed information on this phenomenon. In this type of sociality, the coexistence of solitary and eusocial nests is obligatory, because in the "first" year a female starts the brood rearing alone, and then forms a eusocial nest in the "second" year with her daughters (Sakagami \& Maeta, 1989). Both types of nests are mixed in the population. In our study, Nests A and B contained a large number of cells, but Nests C and $\mathrm{D}$ had just one or two cells. This may represent the coexistence of delayed eusocial and solitary nests in $H$. senilis.

\section{Acknowledgments}

It is a pleasure to thank Dr. Md. Abdul Hannan of Guelph University, Ontario for commenting on the manuscript, Dr. K. Hoshikawa of Shimane University, Matsue for his linguistic expertise in Russian, and Dr. Pesenko of the Zoological Institute, Russian Academy of Sciences, St. Petersburg for identifying the halictine species. This study was supported by Grant-in-Aid for Scietific Research (B) (2) from the Japan Society for the Promotion of Sciences (JSPS) (No. 14405025) (Head Investigator : O. Tadauchi). This is a Contribution from the Entomological laboratory, Faculty of Agriculture, Kyushu University, Fukuoka (Ser. 6, No. 22).

\section{References}

Batra, S. W. T., 1966. Nest and social behavior of halictine bees of India (Hymenoptera: Halictidae). India. J. Ent., 28:375-393.

Malyshev, S. I., 1935. Nesting habits of solitary bees. EOS, 11: 201-309.

Marikovskaya, T. P., 1972. On biology of bees (Apoidae) of the south-east Kazakhstan. Horae Soc. Ent. Union Soviet., 55:187-216. (In Russian.)

Matsumura, T. \& S. F. Sakagami, 1971. Bees from Nepal II. Lasioglossum albescens, with some bionomic notes (Hymenoptera, Halictidae). Ann. Zool. Japoneses, 44: 47-55.

Packer, L. \& G. Knerer, 1986. An analysis of variation in the nest architecture of Halictus ligatus in Ontario. Ins. Soc., 33:190-205.

Popov, V. B., 1967. Bees (Hymenoptera, Apoidae) in central Asia and their utilization of flowering plants. Tr. Zool. Inst. AN SSSR, 38:11-329. (In Russian.)

Sakagami, S. F. \& Y. Maeta, 1989. Compatibility and incompatibility of solitary life with eusociality in two normally solitary bees Ceratina japonica and Ceratina okinawana (Hymenoptera, Apoidea), with notes of the incipient phase of eusociality. Jpn. J. Ent., 57:417-439.

Sakagami, S. F. \& C. D. Michener, 1962. The nest architecture of the sweat bees. A Comparative Study of Behavior. $135 \mathrm{pp}$. Univ. Kansas Press, Lawrence.

Tadauchi, O., 2005. Field studies on wild bee fauna and pollination biology for combating desertification and planting campaigns in Asian arid areas:A report for the year 2000 to 2004. Esakia, (45): 1-8.

Tadauchi, O., R. Miyanaga and A. Dawut, 2005. A new species belonging to the subgenus Euandrena of the genus Andrena from Xinjiang Uygur, China with notes on nest structure (Hymenoptera, Andrenidae). Esakia, (45): 9- 17. 